\title{
Association of the estrogen receptor gene $P v u$ II restriction polymorphism with expected progeny differences for reproductive and performance traits in swine herds in Brazil
}

\author{
Bárbara Amélia Aparecida Santana ${ }^{1}$, Fernando H. Biase ${ }^{2}$, Robson Carlos Antunes ${ }^{3}$, Mauricio Borges ${ }^{4}$, \\ Mauricio Machaim Franco ${ }^{5}$ and Luiz Ricardo Goulart ${ }^{3}$ \\ ${ }^{1}$ Universidade de São Paulo, Faculdade de Medicina de Ribeirão Preto, Departamento de Clínica Médica, \\ Ribeirão Preto, São Paulo, Brazil. \\ ${ }^{2}$ Universidade de São Paulo, Faculdade de Medicina de Ribeirão Preto, Departamento de Genética, \\ Ribeirão Preto, São Paulo, Brazil. \\ ${ }^{3}$ Universidade Federal de Uberlândia, Instituto de Genética e Bioquímica, Uberlândia, Minas Gerais, \\ Brazil. \\ ${ }^{4}$ Consulpec Consultoria em Produção Animal Ltda, Uberlândia, Minas Gerais, Brazil. \\ ${ }^{5}$ Embrapa Recursos Genéticos e Biotecnologia, Laboratório de Genética Molecular Animal, Brasília, \\ DF, Brazil.
}

\begin{abstract}
Estrogen has an important function in swine reproduction and growth. A Pvu ll restriction enzyme polymorphism has been proven to be an important genetic variation in the estrogen receptor gene (ESR) and may be considered as a candidate gene for use in pig production but there is no data regarding the prevalence of this polymorphism in the Brazilian pig population. We used DNA samples from the following three purebred pig breeds: Large White (336 females and 26 males), Landrace (304 females and 27 males) and Pietrain (125 females and 11 males). The ESR genotyping was performed using PCR-RFLP. For each breed, genotypes for the ESR gene were compared independently for expected progeny differences (EPD) in litter size (LS), average daily weight gain (DWG) (g/day) and back fat thickness (BT) as measured in $\mathrm{mm}$ by ultrasound. In the Large White breed, but not the other breeds, the ESR genotype was significantly $(p<0.05)$ associated to $L S$, DWG and BT. Large Whites genotyped as AA or AB had higher EPD values for the LS and BT traits compared to BB Large Whites, while AA Large Whites had higher DWG EPD values than $B B$ Large Whites. Our results for the Large White population showed that the $A$ allele has a beneficial effect on LS, DWG and BT expected progeny differences.
\end{abstract}

Key words: ESR, estrogen receptor, pig.

Received: March 21, 2005; Accepted: August 26, 2005.

\section{Introduction}

Reproduction is an important area that influences swine production performance, but has low heritability (0.1-0.3) for reproductive characteristics (Holm et al., 2004; Rydhmer, 2000). This hampers direct selection of reproductive characteristics by conventional selection mating and this means that selection for litter size in pigs has variable results (Bolet et al., 1989). The genetic components of litter size have been studied and their application permits

Send correspondence to Luiz R. Goulart. Universidade Federal de Uberlândia, Instituto de Genética e Bioquímica, Laboratório de Genética Molecular, Campus Umuarama, Bloco 2E, Sala 24, 38400-902 Uberlândia, MG, Brazil. E-mail: Irgoulart@ufu.br. higher selection indices and consistent results on reproduction improvement (Bennett and Leymaster, 1990). Recently, mammalian genome sequencing projects, construction of gene maps and the discovery of gene polymorphisms by molecular genetics have been adding important information about gene control of physiological pathways of reproductive traits.

Estrogen has an important function on reproduction and growth, estradiol regulating the growth, differentiation and physiology of the reproductive process through the estrogen receptor. Rothschild et al. (1991) identified a $P v u$ II restriction enzyme polymorphism in the estrogen receptor gene in three families of Chinese breeds (Meishan, Fengjing and Minzhu). This polymorphism was associated 
to reproductive and performance traits in Meishan, Large White and Yorkshire breeds (Rothschild et al., 1996; Short et al., 1997). The polymorphism has been proven to be an important genetic variation in the estrogen receptor gene to be studied as a candidate gene for pig production, however, there is no data on the prevalence of this polymorphism in the Brazilian pig population.

The aim of this study was to assess the allele frequency of the estrogen receptor gene (ESR) $P v u$ II polymorphism and evaluate the effect of genotypes on the expected progeny differences (EPD) for litter size (LS), average daily weight gain (DWG) and back fat thickness (BT) in Brazilian Large White, Landrace and Pietrain herds.

\section{Material and Methods}

\section{Swine populations and laboratory analysis}

Three purebred populations from a Brazilian pig farm (Granja Resende S/A Company, Brazil), were used in this study: Large White (336 females and 26 males), Landrace (304 females and 27 males) and Pietrain (125 females and 11 males). Blood samples were collected from each animal in sterile tubes containing EDTA anticoagulant and DNA was extracted as described by Borges (1997). A blood aliquot of $0.5 \mathrm{~mL}$ was added to $0.5 \mathrm{~mL}$ of lysis buffer (Tris-HCL $20 \mathrm{mM}$, sucrose $640 \mathrm{mM}, \mathrm{MgCl}_{2} 10 \mathrm{mM}$ and $4 \%$ Triton $\mathrm{X}-100)$ in a microcentrifuge tube $(2 \mathrm{~mL})$ and the mixture centrifuged for $1 \mathrm{~min}$ at $4,000 \mathrm{x} g$, the leukocytes decanted and the pellet washed three times in the same buffer. After washing, 200- $\mu \mathrm{L}$ of lysis buffer (Tris- $\mathrm{HCl}$ $100 \mathrm{mM}$ (pH 7.5) and 5M guanidine) was added to the nucleated white cell pellet and the mixture incubated at $60{ }^{\circ} \mathrm{C}$ for $30 \mathrm{~min}$, after which the DNA in the supernatant was precipitated with a mixture of $100 \mu \mathrm{L}$ of $150 \mathrm{mM}$ Tris-HCL (pH 7.5), 1.2 M ammonium acetate and $300 \mu \mathrm{L}$ of $100 \%$ isopropanol and then centrifuged for $5 \mathrm{~min}$ at $4,000 \mathrm{x}$. After centrifugation the DNA pellet was washed twice in $1 \mathrm{~mL}$ of aqueous ethanol (70\%), eluted in $300-500 \mu \mathrm{L}$ of TE buffer (Tris $10 \mathrm{mM}$; EDTA $1 \mathrm{mM}$ ) and stored at $-20{ }^{\circ} \mathrm{C}$ until used.

The estrogen receptor genotype was identified using the polymerase chain reaction - fragment length polymorphism (PCR-RFLP) method as reported by Short et al. (1997). The primers used for the PCR reactions were 5CCTGTTTTTACAGTGACTTTTACAGAG-3 and 5CACTTCGAGGGTCAGTCCAATTAG-3 and the PCR conditions were: 100ng of genomic DNA, 1x PCR buffer (Invitrogen), $1.5 \mathrm{mM} \mathrm{MgCl}_{2}, 5 \mu \mathrm{M}$ of each primer, $100 \mu \mathrm{M}$ of each dNTP and $1 \mathrm{U}$ of Taq DNA polymerase (Invitrogen) in a final volume of $20 \mu \mathrm{L}$. The reactions were performed in a MJ Research PTC-100 thermocycler by heating the tubes at $95^{\circ} \mathrm{C}$ for $5 \mathrm{~min}$ followed by 35 cycles of $95^{\circ} \mathrm{C}$ for $45 \mathrm{~s}$, $55^{\circ} \mathrm{C}$ for $40 \mathrm{~s}$ and $72{ }^{\circ} \mathrm{C}$ for $45 \mathrm{~s}$, followed by a final extension of $72{ }^{\circ} \mathrm{C}$ for $5 \mathrm{~min}$. The amplicons $(120 \mathrm{bp})$ were di- gested using the Proteus vulgaris Pvu II restriction enzyme at $37^{\circ} \mathrm{C}$ for $15 \mathrm{~h}$ and then submitted to electrophoresis on $3.5 \%(\mathrm{w} / \mathrm{v})$ agarose gel containing $50 \mu \mathrm{g} \mathrm{mL}^{-1}$ of ethidium bromide (Sambrook et al., 2001) and visualized under UV light. The genotypes, described in detail by Short et al. (1997) were AA (120bp), AB (120bp, 65bp, 55bp) and BB (65bp, 55bp).

\section{Statistical analysis}

Population analysis was performed using the Genepop software (Raymond and Rousset, 1995) applying the default parameters. Genotypic and allelic frequencies were calculated independently for each breed (Weir and Cockerham, 1984) and allelic frequencies were compared between each breed pair using the Chi-squared $\left(\chi^{2}\right)$ test and applying a contingency table (Raymond and Rousset, 1995).

Expected progeny differences (EPD) for litter size (LS) for all parities, average daily weight gain (DWG, $\mathrm{g} \mathrm{d}^{-1}$ ) between 63 and 140 days, and back fat thickness (BT) in $\mathrm{mm}$ obtained by ultrasound measurements were estimated and kindely provided by personnel at Granja Resende S/A which maintains a selection program based on the breeding values of their animals estimated by a complete animal model applying best linear unbiased prediction (BLUP) (Boldman et al., 1995). For each breed, ESR gene genotypes were independently compared for each trait using analysis of variance (ANOVA) and the EPD means were compared among the genotypes using Duncan's Multiple Range Test. Both tests were performed using the Statistical Analysis Software (SAS Institute Inc., 2001). The linear model fitted for ANOVA was: $Y_{i j}: \mu+G_{i}+e_{i j}$, where $Y_{i j}$ is the EPD for each trait of the $i j^{\text {th }}$ animal, $\mu$ is the general mean of each trait, $\mathrm{G}_{\mathrm{i}}$ is the fixed effect of the $i^{\text {th }} \operatorname{ESR}(P v u$ II) genotype and $e_{i j}$ is the random error effect associated to the $i j^{\text {th }}$ observation. Results were considered statistically significant when $\mathrm{p}<0.05$.

\section{Results}

Allele and genotypic frequencies calculated for each breed are presented in Table 1. The allelic distribution was different across the three breeds $(\mathrm{p}<0.001)$.

Due to the fixed allele A in Pietrain animals, analysis of variance and the mean contrast test were performed only for Landrace and Large White data (Table 2). Although Landrace pigs genotyped as BB had higher EPD values than $\mathrm{AA}$ or $\mathrm{AB}$ animals for the LS, DWG and BT traits, the differences were not statistically significant $(p>0.05)$. However, in the Large White breed the estrogen receptor genotype was significantly associated $(p<0.05)$ with litter size, average daily weight gain and back fat thickness. Animals genotyped as AA or AB had higher EPD values compared to the $\mathrm{BB}$ animals for $\mathrm{LS}$ and $\mathrm{BT}$ traits, and $\mathrm{AA}$ 
Table 1 - Allele and genotype frequencies for the estrogen receptor gene (ESR) in Landrace, Large White and Pietrain swine breeds.

\begin{tabular}{lllllllll}
\hline \multirow{2}{*}{ Breeds } & \multirow{2}{*}{$\mathrm{N}$} & \multicolumn{3}{c}{ ESR genotype frequencies } & & \multicolumn{2}{c}{ ESR allele frequencies } \\
\cline { 3 - 5 } \cline { 7 - 8 } & & \multicolumn{2}{c}{ AA } & AB & BB & & A & B \\
\hline Landrace & 362 & 0.6547 & 0.3094 & 0.0359 & & 0.8094 & 0.1906 \\
Large White & 331 & 0.4562 & 0.4532 & 0.0906 & & 0.6828 & 0.3172 \\
Pietrain & 136 & 1 & 0 & & 0 & & 1 & 0 \\
\hline
\end{tabular}

animals had higher EPD values than BB animals for DWG (Table 2).

\section{Discussion}

The estrogen receptor gene has been studied as an important marker for genetic improvement for reproductive traits in swine breeding programs, especially in Large White, Meishan and Yorkshire purebreds or derived crossbreds.

There is no data reporting the ESR ( $P v u$ II) restriction polymorphism in Pietrain swine pigs. In this study the A alleles were fixed in Pietrain, but not in the Landrace and Large White swine populations.

In a study of 91 German Landrace boars for the $P v u$ II polymorphism Drogemuller et al (2001) found that all the boars were AA homozygous, so the fact that the Brazilian Landrace population studied by us was polymorphic for the $P v u$ II site (AA, AB and BB) may be due to the different genetic background between populations. Despite the presence of the polymorphic $P v u$ II site in the Brazilian Landrace animals, there were no differences among ESR genotypes in the expected progeny differences (EPD) for litter size (LS), average daily weight gain (DWG) and back fat thickness (BT) traits.

Breeding programs have selected females for reproductive efficiency and the controlled matings to improve the number of pigs born may have interfered with the estrogen receptor (ESR) allele frequency because it seems to have a significant effect on litter size (Rothschild, 1996).
The ESR allele frequencies in the Brazilian Large White population was $\mathrm{A}=0.68$ and was different from that reported for other populations, i.e. $\mathrm{A}=0.59$ (Rothschild et al., 1996), $\mathrm{A}=0.59$ to 0.43 (Short et al., 1997) and $\mathrm{A}=0.60$ (Isler et al., 2002), although this difference was statistically significant $(\mathrm{p}=0.004)$ only when our data were compared to the lower frequency $(\mathrm{A}=0.43)$ reported by Short et al. (1997).

The ESR gene has been analyzed and associated to reproductive or performance traits, with Rothschild et al. (1996) having demonstrated that the B allele in Meishan and Large White synthetic lines had an additive effect for total number of pigs born and for the number of pigs born alive in the first parity and considering all parities. For Meishan and Large White, there were no genotype effects on performance traits (average daily gain, back fat thickness, and functional nipples). Short et al. (1997) studied the ESR polymorphism in four Large White-based commercial lines and found that the B allele had an additive effect for the total number of pigs born and number of pigs born alive in the first parity and in later parities and there were also additive effects for B allele for back fat and for test average daily feed consumed. In different Meishan x Large White $\mathrm{F}_{2}$ populations analyzed by Gibson et al. (2002) no additive $\mathrm{B}$ allele effects were found for nine reproductive traits. However, in another study with a synthetic breed $(50 \%$ Meishan $/ 50 \%$ Landrace) van Rens et al. (2002) found that the $\mathrm{AB}$ genotype produced a higher total number of pigs born and number of pigs born alive than the BB genotype.

Table 2 - Number of observations, expected progeny difference (EPD) mean and standard deviation values for litter size (LS), daily weight gain (DWG) and back fat thickness (BT) traits in 362 Landrace and 331 Large White breeds genotyped for the estrogen receptor gene.

\begin{tabular}{|c|c|c|c|c|}
\hline \multirow{2}{*}{$\frac{\text { Breed }}{\text { Landrace }}$} & \multirow[t]{2}{*}{ Trait* } & \multicolumn{3}{|c|}{ Genotype (EPD mean value \pm standard error) } \\
\hline & & AA (237) & $\mathrm{AB}(112)$ & $\mathrm{BB}(13)$ \\
\hline & LS & $0.26 \pm 0.01^{\mathrm{a}}$ & $0.23 \pm 0.01^{\mathrm{a}}$ & $0.30 \pm 0.04^{\mathrm{a}}$ \\
\hline & DWG & $60.21 \pm 1.55^{\mathrm{a}}$ & $52.39 \pm 2.42^{\mathrm{a}}$ & $61.17 \pm 3.55^{\mathrm{a}}$ \\
\hline & BT & $-0.45 \pm 0.025^{\mathrm{a}}$ & $-0.45 \pm 0.03^{\mathrm{a}}$ & $-0.40 \pm 0.08^{\mathrm{a}}$ \\
\hline \multirow[t]{4}{*}{ Large white } & & AA (151) & $\mathrm{AB}(150)$ & $\mathrm{BB}(30)$ \\
\hline & LS & $0.00 \pm 0.00^{\mathrm{a}}$ & $0.00 \pm 0.00^{\mathrm{a}}$ & $-0.06 \pm 0.01^{\mathrm{b}}$ \\
\hline & DWG & $45.11 \pm 2.23^{\mathrm{a}}$ & $40.58 \pm 2.19^{\mathrm{ab}}$ & $34.72 \pm 4.87^{\mathrm{b}}$ \\
\hline & BT & $-0.05 \pm 0.04^{\mathrm{a}}$ & $-0.14 \pm 0.03^{\mathrm{a}}$ & $-0.33 \pm 0.05^{\mathrm{b}}$ \\
\hline
\end{tabular}

*LS: litter size, DWG: average daily weight gain (gram/day), BT: back fat thickness (mm). ${ }^{\text {ab }}$ Means within a row with different superscript letters are different $(\mathrm{p}<0.05)$. 
Isler et al. (2002) genotyped a population of Yorkshire, Large White and crossbred animals and found that the AA genotype had higher values for total weight of animals born $(\mathrm{kg})$ and total weight of animals born alive $(\mathrm{kg})$ than had the AB or BB genotypes. Goliasova and Wolf (2004) analyzed a Large White population for the ESR polymorphism and found that the AA genotype had better performance over all parities for number of piglets born alive, total number of piglets born per litter, number of piglets weaned per litter and litter weight at weaning.

All the published results were performed with real data collected from each analyzed trait. In our study we analyzed the expected progeny difference (EPD) estimated from real data and compared among ESR genotypes. The EPD is based on the estimated value of the additive genetic component of the analyzed trait; therefore, EPDs are effective estimates for additive genetic variation in the pigs (Boldman et al., 1995). In our study of the first Brazilian Large White pig population ever analyzed for the ESR $P v u$ II polymorphism the AA genotyped animals had statistically higher $(\mathrm{p}<0.05)$ EPD values for litter size $(\mathrm{LS})$, average daily weight gain (DWG) and back fat thickness (BT) in comparison to BB pigs from the same population (Table 2).

Rothschild et al. (1996) have postulated that the influence of the ESR genotype on the different number of piglets born was associated with embryo survival, probably because of the important role of estrogen in the maternal recognition of the conceptus (Spencer and Bazer, 2004). However, pre-ovulatory hormones (luteinizing hormone (LH), estradiol and progesterone), number of embryos at day 35/36 of gestation, weight of embryos and viable embryos did not differ between AA and AB ESR genotypes in Meishan/Landrace animals (van Rens et al., 2000). Moreover, there was no significant $B$ allele additive effect on ovulation rate in a Landrade/Large White population studied by Linville et al. (2001). These results produced by various authors suggest that the effect of the estrogen receptor gene could be associated to percentage fetal survival and/or may be also associated to the success of embryo implantation (Damario et al., 2001).

Analyses of the ESR locus have shown that there is a divergence between the beneficial allele that could be associated with the improvement over reproductive or performance traits in pigs. Rothschild et al. (1996) constructed a linkage map near the estrogen receptor gene and found that the ESR gene polymorphism seems to be responsible for the phenotypic variation in beneficial traits, suggesting that the genetic background of breeds might affect the control of gene expression. Whether the ESR gene is linked to other important major gene or whether it is the major gene associated to litter size and performance traits, and the mechanism by which this gene influences these traits is still unknown.
Our analysis in this Brazilian Large White population showed that the A allele is a favorable allele for expected progeny differences in litter size, average daily weight gain and back fat thickness. Although the average difference of -0.06 pig observed in the BB genotyped animals was statistically significant in the contrast test, the pig industry must study how cost-effective genotyping herds would be. Moreover, studies with a larger data set should be carried out to obtain information about the genetic background of Landrace and Large White swine breeds in Brazil in order to confirm whether or not the estrogen receptor gene $P v u$ II restriction polymorphism could act as a good marker to help improve reproductive and performance traits in Brazilian swine production.

\section{Acknowledgments}

The authors thank Isabel Regina Scheid and José Antonio Galo for helpful discussions, the Brazilian agency CAPES financial support and Granja Rezende S/A for providing the swine blood samples and breeding values.

\section{References}

Bennett GL and Leymaster KA (1990) Genetic implications of a simulation model of litter size in swine based on ovulation rate, potential embryonic viability and uterine capacity: I. Genetic theory. J Anim Sci 68:969-979.

Boldman K, Van Vleck L, Kriese L and Kachman S (1995) MTDFREML: User's Guide. Departament of Agriculture/ Agricultural Research Service, Lincon, 112 pp.

Bolet G, Ollivier L and Dando P (1989) Sélection sur la prolificité chez le porc. I. Résultats d'une expérience de sélection sur onze générations. Genet Sel Evol 21:93-106.

Borges M (1997) Marcadores moleculares e seus efeitos sobre características quantitativas de bovinos de corte. Doutorado, Universidade de Uberlândia, Uberlândia.

Damario MA, Lesnick TG, Lessey BA, Kowalik A, Mandelin E, Seppälä M and Rosenwaks Z (2001) Endometrial markers of uterine receptivity utilizing the donor oocyte model. Hum Reprod 16:1893-1899.

Drogemuller C, Hamann H and Distl O (2001) Candidate gene markers for litter size in different German pig lines. J Anim Sci 79:2565-2570.

Gibson JP, Jiang ZH, Robinson JA, Archibald AL and Haley CS (2002) No detectable association of the ESR PvuII mutation with sow productivity in a Meishan x Large White F2 population. Anim Genet 33:448-450.

Goliasova E and Wolf J (2004) Impact of the ESR gene on litter size and production traits in Czech Large White pigs. Anim Genet 35:293-297.

Holm B, Bakken M, Klemetsdal G and Vangen O (2004) Genetic correlations between reproduction and production traits in swine. J Anim Sci 82:3458-3464.

Isler BJ, Irvin KM, Neal SM, Moeller SJ and Davis ME (2002) Examination of the relationship between the estrogen receptor gene and reproductive traits in swine. J Anim Sci 80:2334-2339. 
Linville RC, Pomp D, Johnson RK and Rothschild MF (2001) Candidate gene analysis for loci affecting litter size and ovulation rate in swine. Journal of Animal Science 79:60-67.

Raymond M and Rousset F (1995) GENEPOP (version 1.2): Population genetics software for exact tests and ecumenicism. J Hered 86:248-249.

Rothschild MF (1996) Genetics and reproduction in the pig. Animal Reproduction Science 42:143-151.

Rothschild M, Jacobson C, Vaske D, Tuggle C, Wang L, Short T, Eckardt G, Sasaki S, Vincent A, McLaren D, Southwood O, van der Steen H, Mileham A and Plastow G (1996) The estrogen receptor locus is associated with a major gene influencing litter size in pigs. Proc Natl Acad Sci USA 93:201-205.

Rothschild MF, Larson RG, Jacobson C and Pearson P (1991) Pvu II polymorphisms at the porcine oestrogen receptor locus (ESR). Anim Genet 22:448.

Rydhmer L (2000) Genetics of sow reproduction, including puberty, oestrus, pregnancy, farrowing and lactation. Livest Prod Sci 66:1.
Sambrook J, Fritch EF and Maniatis T (2001) Molecular Cloning: A Laboratory Manual. 3. Cold Spring Harbor Laboratory Press, New York, 18.136 pp.

SAS Institute Inc. (2001) Statistical Analysis Software. 8.2. SAS Institute Inc., Cary, (CDROM).

Short TH, Rothschild MF, Southwood OI, McLaren DG, de Vries A, van der Steen H, Eckardt GR, Tuggle CK, Helm J, Vaske DA, Mileham AJ and Plastow GS (1997) Effect of the estrogen receptor locus on reproduction and production traits in four commercial pig lines. J Anim Sci 75:3138-3142.

Spencer TE and Bazer FW (2004) Conceptus signals for establishment and maintenance of pregnancy. Reprod Biol Endocrinol 2:49. http://www.rbej.com.

van Rens BTTM, Hazeleger W and van der Lende T (2000) Periovulatory hormone profiles and components of litter size in gilts with different estrogen receptor (ESR) genotypes. Theriogenology 53:1375.

Weir BS and Cockerham CC (1984) Estimating F-statistics for the analysis of population structure. Evolution 38:1358-1370.

Associate Editor: Pedro Franklin Barbosa 